\title{
Understanding blunt force trauma and violence in Neolithic Europe: the first experiments using a skin-skull-brain model and the Thames Beater
}

Meaghan Dyer \& Linda Fibiger*

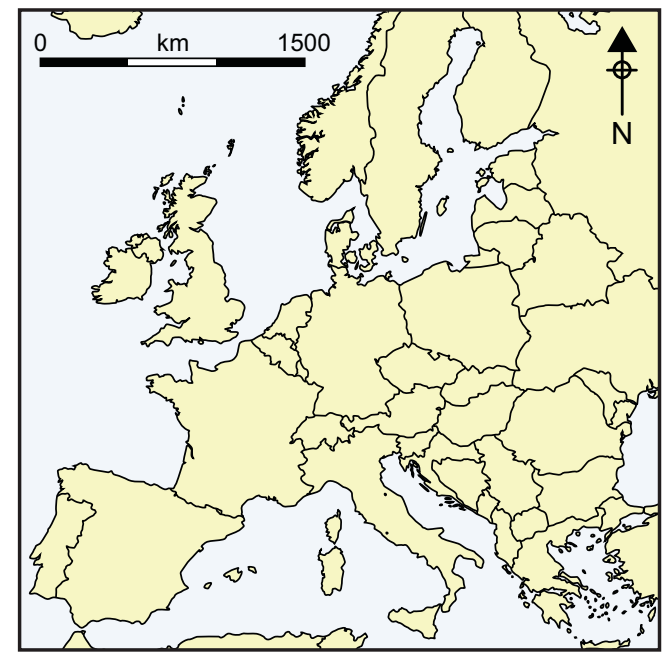

The difficulty in identifying acts of intentional injury in the past has limited the extent to which archaeologists have been able to discuss the nature of interpersonal violence in prehistory. Experimental replication of cranial trauma has proved particularly problematic due to the lack of test analogues that are sufficiently comparable to the human skull. A new material now overcomes this issue, and for the first time allows accurate insight into the effects of different weapons and different blows in inflicting cranial injury; in this case, blunt force trauma caused using a replica of the 'Thames Beater' Neolithic wooden club.

Keywords: Western Europe, Neolithic, interpersonal violence, weapon-tools, blunt force trauma, skin-skull-brain model, experimental archaeology

\section{Introduction}

Evidence of blunt force cranial trauma incurred through interpersonal violence has been firmly established in recent population studies of the British and European Neolithic (Schulting \& Wysocki 2005: 107; Lawrence 2006: 53; Smith \& Brickley 2007: 25; McKinley 2008: 477; Ahlström \& Molnar 2012: 17; Schulting 2012: 223; Schulting \& Fibiger 2012; Fibiger et al. 2013: 190; Meyer et al. 2015: 11217). Experimental studies on the means by which these injuries were sustained can greatly aid our understanding of the variable causes and contexts of violence and, more generally, the nature of social interactions in prehistory (Wedel \& Galloway 2014: 73). Hitherto, however, there has been

* School of History, Classics and Archaeology, William Robertson Wing, Old Medical School Building, 4 Teviot Place, Edinburgh EH8 9AG, UK (Email:s1057196@sms.ed.ac.uk; linda.fibiger@ed.ac.uk) 
very little research to identify the specific implements responsible for these types of injury in prehistory.

Experimental studies of blunt force trauma in other time periods have often used human cadavers or animal proxies when attempting to replicate intentional injuries, although both of these mediums are often either susceptible to major faults in accuracy, or raise various questions about their ethicality (Corey et al. 2001: 104; Thali et al. 2002a: 199, 2002b: 178; Byard et al. 2007: 31; Raul et al. 2008: 359; Wedel \& Galloway 2014: 140; Smith et al. 2015: 427). In recent years, however, new methods using synthetic 'skin-skull-brain' models have begun to emerge as an alternative. These polyurethane human skull substitutes are made to uniform specification, meaning that they avoid the inaccuracies and ethical issues of using animal substitutes or human cadavers (Thali et al. 2002a: 195, 2002b: 178; Smith et al. 2015: 427).

This article presents the results of the first use of skin-skull-brain models to investigate the causes of blunt force trauma in the Neolithic osteological record. A replica of the 'Thames Beater', a Neolithic wooden club, was able to produce fractures in synthetic skulls with remarkable similarities to those found on Neolithic skeletal remains from Asparn/Schletz, a massacre site in Austria (Teschler-Nicola 2012: 107), thereby demonstrating the suitability of this method for providing appropriate test analogues. The research opens up new and innovative avenues for exploring the mechanisms and context of blunt force trauma in prehistory. This is essential for understanding the meaning of the social and cultural contexts of such events (as varying forms of violence are indicative of different social pressures and interactions), whether considering material from standard funerary contexts or the increasing number of remains from mass graves across Western and Central Europe (e.g. Schulting \& Fibiger 2012: 2; Teschler-Nicola 2012: 101; Fibiger et al. 2013: 191; Chenal et al. 2015: 1329).

\section{Blunt force trauma}

Many mechanisms of injury can cause blunt force trauma, and the limited ways in which bone can react to an impact—whether violent or accidental—can complicate diagnosing the intentionality behind an injury (Alcantara et al. 1994: 521; Lovell 1997: 148; Raul et al. 2008: 359; Jacobsen et al. 2009: 2; Sharkey et al. 2012: 835; Wedel \& Galloway 2014: 33). Cranial fractures are more often indicative of intentional violence than postcranial trauma (Lovell 1997: 149; Chattopadhyay \& Tripathi 2010: 102; Schulting 2012: 224; Fibiger et al. 2013: 191). Certain fractures, however, are often discounted as the result of accidentally incurred trauma (Lovell 1997: 150; Ortner 2003: 121; Freeman et al. 2014: 64).

Fracture formation from blunt force trauma to the cranium is influenced by the biomechanical properties of the skull (Lovell 1997: 155; Kasrai et al. 1999: 238; Wedel \& Galloway 2014: 134; Carr et al. 2015: 508). Cranial sutures (the joints between the bones of the skull) are able to absorb force, and can stop the progression of fractures across the surface of the cranium (Lovell 1997: 155; Wedel \& Galloway 2014: 135). The skull is also buttressed with arched areas of thicker bone; fractures follow the path of least resistance and can be influenced by these patterns of strong and weak bone in the skull (C) Antiquity Publications Ltd, 2017 


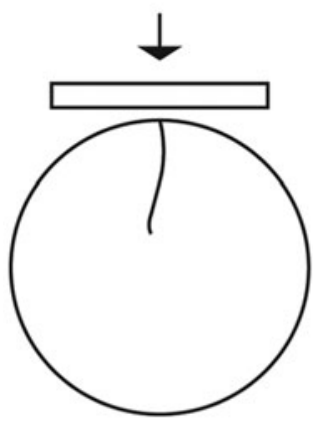

linear

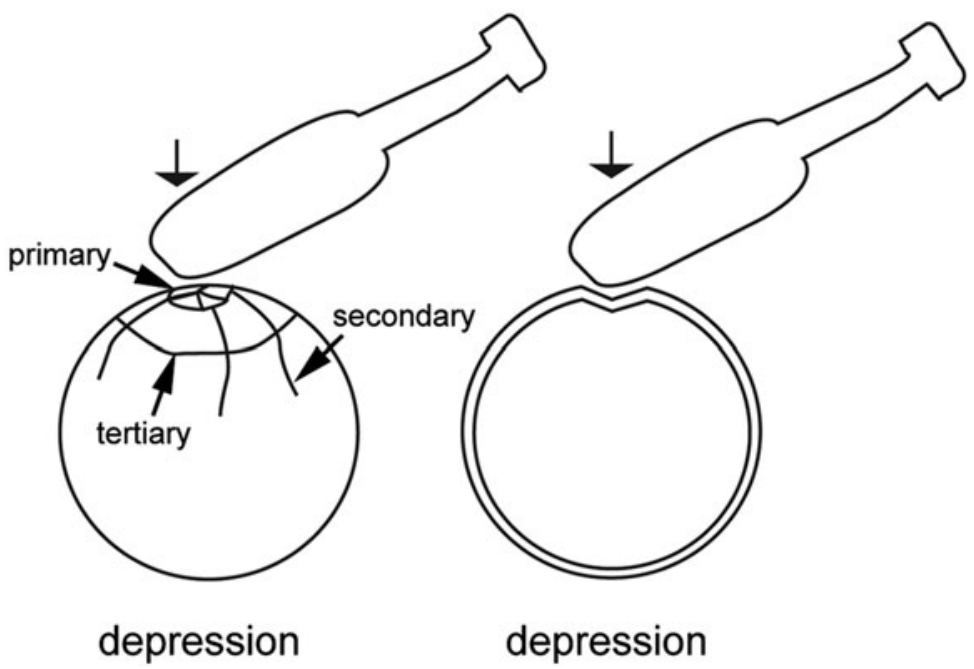

Figure 1. Diagram showing three views of blunt force cranial fracture: left) a linear fracture; centre) the exterior of a depression fracture showing the primary impact site along with the secondary and tertiary fractures that may form on the surface of the cranium; right) the internal view of a depression fracture showing the in-bending created at the site of impact (photograph: Meaghan Dyer).

(Lovell 1997: 155; Kasrai et al. 1999: 238; Wedel \& Galloway 2014: 141; Carr et al. 2015: 508).

Several types of fracture are formed by blunt force trauma (Figure 1). Linear fractures are produced when a low-velocity force is transmitted through a wide surface area; accidental injuries, such as falls, are possible causes, leading linear fractures to be ruled out of many archaeological studies of violence (Lovell 1997: 150; Ortner 2003: 121; Schulting \& Wysocki 2005: 110; Freeman et al. 2014: 64; Wedel \& Galloway 2014: 137).

Depressions and penetrating blunt force fractures, formed by higher velocity and more concentrated force patterns, are more closely associated with armed blows (Oh 1983: 111; Lovell 1997: 154; Ortner 2003: 121; Schulting \& Wysocki 2005: 110; Schulting 2012: 225; Wedel \& Galloway 2014: 62). 'In-bending', the process by which the skull table is forced inward towards the brain during a blow, creates bevelled, displaced bone at the impact site, that—along with secondary and tertiary fractures, which form additional fractures radiating out from or circling the impact site-is characteristic of depression fractures (Figure 1) (Oh 1983: 116; Lovell 1997: 150; Ortner 2003: 121; Calc \& Rogers 2007: 519; Wedel \& Galloway 2014: 129; Smith et al. 2015: 428).

\section{The Neolithic osteological record: north-west Europe}

Skeletal evidence represents the minimum number of injuries that occurred in a past population. Assessments of the skeletal record of Britain and Europe during the Neolithic have clearly established the presence of both healed and peri-mortem examples of intentionally delivered blunt force trauma (Ahlström \& Molnar 2012: 17; Schulting 2012: 
223; Fibiger et al. 2013: 190; Fibiger 2014; Meyer et al. 2015: 11217). Healed trauma tends to be more prevalent in male skeletons, while peri-mortem trauma is more evenly distributed between the sexes. Overall, there is a higher prevalence of trauma in males, which suggests that they were the principal actors and instigators of violent interaction (Schulting \& Wysocki 2005: 123; Ahlström \& Molnar 2012: 17; Schulting 2012; Fibiger et al. 2013: 190). The social and cultural context of this violence is still heavily debated, and a better understanding of the implements used for causing these injuries would greatly aid such interpretation.

The identification of weapon typologies can help to establish if certain classes of tool were used opportunistically as weapons, or designed specifically for interpersonal violence, and how this relates to differences in the osteological evidence (Schulting \& Wysocki 2005: 107; Ahlström \& Molnar 2012: 17; Schulting 2012: 228; Fibiger et al. 2013: 190). Establishing whether implements used at massacre sites differ from those associated with injuries commonly found in standard funerary contexts may demonstrate similarities or discrepancies between the causes.

\section{Neolithic weapons of violence and the Thames Beater}

Implements recovered from the material record of Neolithic Britain and north-western Europe are difficult to classify unambiguously as weapons of violence (Christensen 2004: 139; Fowler 2010: 16; Fibiger et al. 2013: 191). Instead, potential weapons, including bows and arrows, axes, clubs and possible sling-type tools must all be considered. Current studies have yet to establish which of these implements may have been used as blunt force weapons, and mostly discuss the blunt force mechanism of injury alone, only speculating on the particular implements used (Schulting \& Wysocki 2005: 125; Smith \& Brickley 2007: 25; Lorkiewicz 2011: 432; Ahlström \& Molnar 2012: 27; Schulting 2012: 224; Schulting \& Fibiger 2012: 2; Fibiger et al. 2013: 199; Meyer et al. 2015: 11220).

The Thames Beater is an alder club that was found in the Thames River near Chelsea and radiocarbon dated to the Early British Neolithic (Webber \& Ganiaris 2004: 126). It is one of a very small number of wooden clubs that survive from the Neolithic period in Britain (Webber \& Ganiaris 2004: 126; Schulting \& Wysocki 2005: 125). The artefact is on exhibition at the Museum of London, and a replica was produced by master carpenter David Lewis from Pelynt, Cornwall (Figure 2). Alder was also used for the replica to create an accurate reproduction of the weight, strength and other physical properties of the original artefact. The completed replica (Figure 2) measures $640 \mathrm{~mm}$ in length (Table 1) and comprises a slightly angled 'blade', barrel and pommel (Webber \& Ganiaris 2004: 124).

Wooden clubs have commonly been (and still are) used as weapons in a variety of cultures across time and space (Walker 1989: 319; Webber \& Ganiaris 2004: 124; Dujovny et al. 2009: 1005). The low number of examples known from the Neolithic probably reflects the poor preservation of organic materials from the period, rather than their scarcity during this time (Webber \& Ganiaris 2004: 126; Schulting \& Wysocki 2005: 125; Ahlström \& Molnar 2012). The study of clubs that have survived can greatly aid in furthering our understanding of their potential use as weapons.

(C) Antiquity Publications Ltd, 2017 
Table 1. Dimensions and weight of the Thames Beater replica.

\begin{tabular}{lc}
\hline Measurement & mm \\
\hline & \\
Maximum length & 648 \\
Blade length & 324 \\
Barrel length & 225 \\
Pommel length & 99 \\
Pommel width & 88.9 \\
Pommel thickness & 58.3 \\
Length of blade tip & 57.5 \\
Circumference of barrel (pommel end) & 136 \\
Circumference of barrel (midpoint) & 160 \\
Circumference of barrel (blade end) & 154 \\
\hline Weight & $1.17(\mathrm{~kg})$ \\
\hline
\end{tabular}

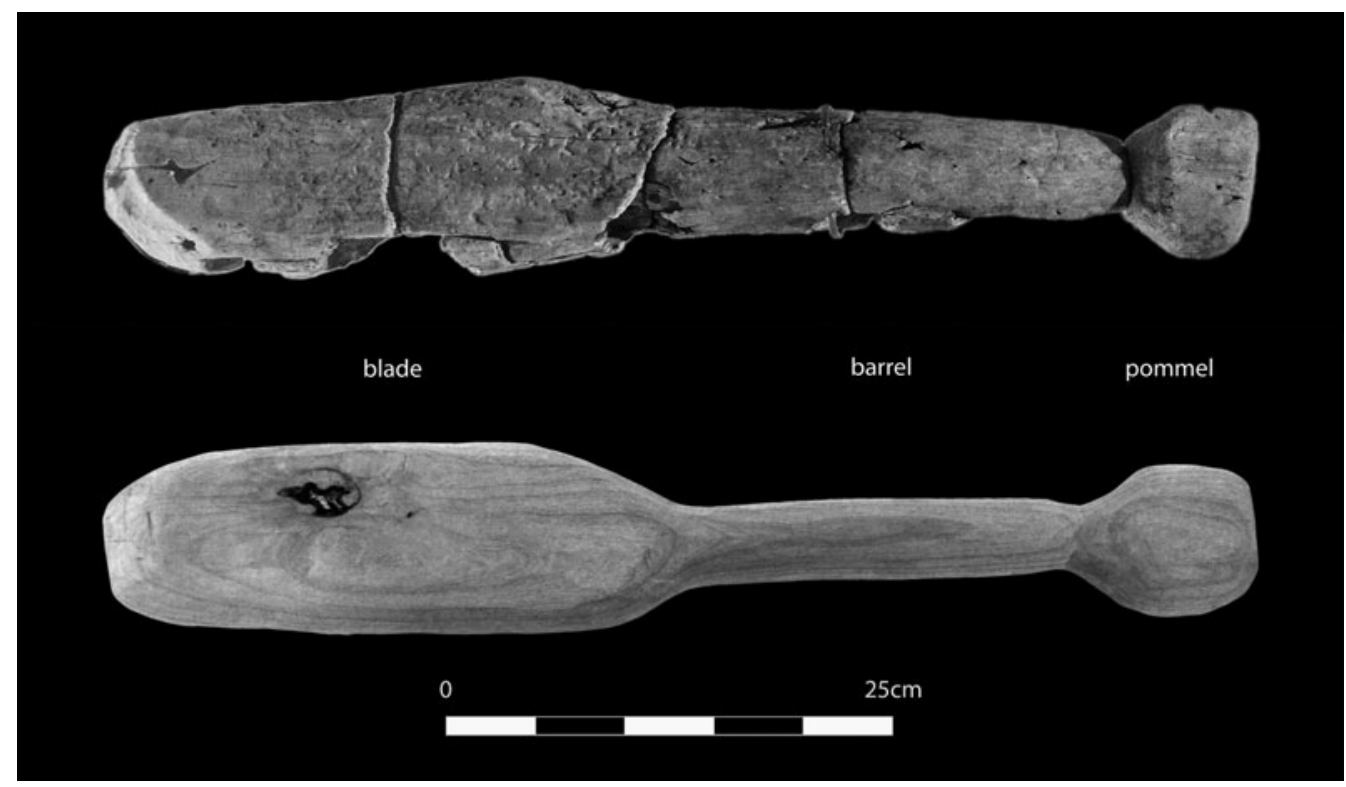

Figure 2. The Thames Beater (top) and the replica club used for experimentation (bottom) with the blade, barrel and pommel labelled (photograph: Meaghan Dyer).

\section{Method}

The synthetic bone spheres used for the skin-skull-brain models (Figure 3) were produced by Synbone AG (Switzerland). Two $5 \mathrm{~mm}$ and two $7 \mathrm{~mm}$ spheres were selected. The spheres consist of two halves of specialised polyurethane material glued together and coated in an external rubber skin to simulate part of the outer soft tissue of the skull (Synbone AG 2013). The base of the sphere has a central hole, through which it is filled with ballistics gelatin. Four of these spheres were used, two with $5 \mathrm{~mm}$-thick walls and two with $7 \mathrm{~mm}$-thick walls, 


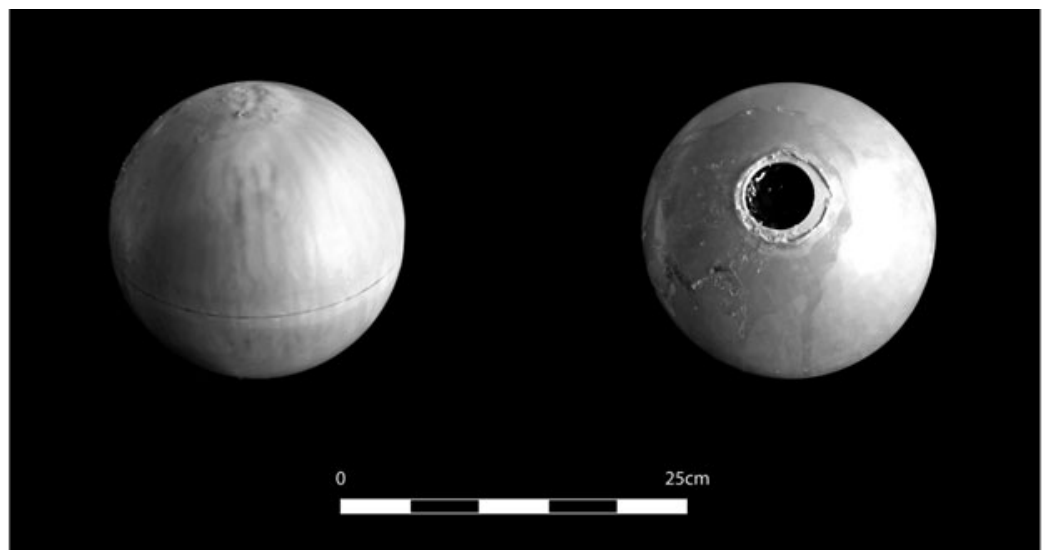

Figure 3. The assembled synthetic bone sphere: left) showing the join between the two hemispheres; right) showing the aperture at the base of the sphere (photograph: Meaghan Dyer).

to account for variation in skull thickness between individuals (Getz 1961: 221; Adeloye et al. 1975: 23; Lieberman 1996: 223; Lynnerup 2001: 45).

Previous studies carried out on synthetic bone have demonstrated the need for the spheres to be filled in order to recreate accurate fracturing (Carr et al. 2015: 506; Smith et al. 2015: 428). A 10 per cent solution of ordnance level ballistics gelatin, which approximates the density of human soft tissue, was used to fill the spheres (Fackler \& Malinowski 1988: 219; Jussila 2004: 91; Carr et al. 2015: 506; Smith et al. 2015: 428).

Once constructed, the skin-skull-brain spheres were placed on an elevated platform $1.08 \mathrm{~m}$ high, supported on a cork ring $31 \mathrm{~mm}$ tall and $138 \mathrm{~mm}$ in diameter. The hole in the sphere was placed facing down. A right-handed adult male, aged 30, $1.93 \mathrm{~m}$ tall and weighing $88.5 \mathrm{~kg}$, delivered the strikes.

Two types of blow were administered to investigate variable fracture patterns produced by different areas of the club. Figure 4 shows the hand positions for administering the pommel blow and the double-handed blade strike. Each type of strike was delivered once to one $5 \mathrm{~mm}$ and one $7 \mathrm{~mm}$ sphere to allow each wall thickness to be observed when struck with the pommel and the blade. For the double-handed strikes, the club was swung through the air and down onto the sphere, contacting at the end of the blade. To deliver the blows with the pommel, the club was drawn up above, aimed and brought down upon the sphere. The strikes with the pommel carried notably less force. Once struck, the resulting fractures were examined, measured and photographed, before and after the rubber skin, and then the gelatin, were removed.

\section{Results}

The double-handed blade strikes produced relatively extensive depression fractures in both the $7 \mathrm{~mm}$ - and $5 \mathrm{~mm}$-thick sphere walls. As seen in Table 2 and Figure 5, the impact site on the spheres displaced pieces of bone. Differing numbers of radiating fractures also spread out from the area of impact. This is typical of extensive blunt force trauma (Oh 1983: 116; Lovell 1997: 150; Ortner 2003: 121; Calc \& Rogers 2007: 519; Wedel \& Galloway (C) Antiquity Publications Ltd, 2017 


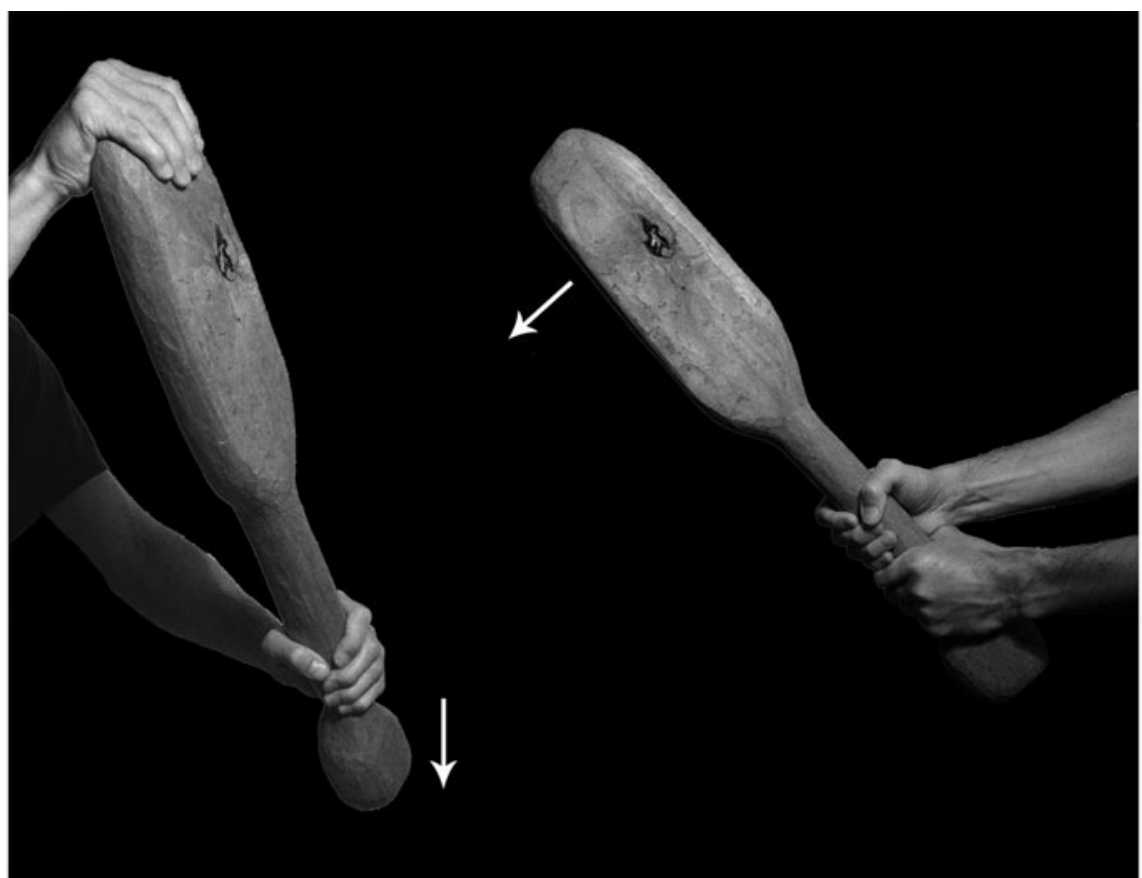

Figure 4. The hand positions used to administer the two types of blow: left) the pommel strike; right) the double-handed strike. Arrows indicate direction of swing (photograph: Meaghan Dyer).

2014: 129; Smith et al. 2015: 428). In the 5mm-thick sphere, the fractures became linked by circular tertiary fractures caused by further 'out-bending', which forms when the force of the impact causes the skull to push out around the area of impact, creating extensively displaced fragments of bone.

The pommel strikes differed significantly from the predicted results that the blows would produce small, shallow depressed fractures. Both the $5 \mathrm{~mm}$ - and $7 \mathrm{~mm}$-thick sphere walls had long linear fractures extending from the point of impact, as listed in Table 2. These fractures ran in opposite directions from the area of initial impact (Figure 6).

\section{Discussion}

\section{Synthetic bone as an accurate medium}

Despite previous problems in comparing synthetic polyurethane bone with living human tissue at the microscopic level (Smith et al. 2015: 427), the present study confirms the ability of a skin-skull-brain model to provide clear results for testing the macroscopic appearance of archaeological blunt force trauma. The depression and linear fractures formed in the skin-skull-brain models display the characteristics of human skull fractures. The internal bevelling of fractured synthetic bone fragments, as seen in Figure 7, along with the formation of radiating secondary and tertiary fractures (Figure 5), are major diagnostic features of blunt force trauma. 
Table 2. Summary of fractures produced with the skin-skull-brain models. (Note that the size of depression fractures relates to the area of depressed bone created at the impact location, and not the bone displaced by intersecting radiating fractures.)

\begin{tabular}{|c|c|c|c|c|c|}
\hline $\begin{array}{l}\text { Sphere wall } \\
\text { thickness }\end{array}$ & Type of blow & $\begin{array}{l}\text { Fracture } \\
\text { produced }\end{array}$ & Length & Width & $\begin{array}{l}\text { Secondary/tertiary } \\
\text { fractures }\end{array}$ \\
\hline $7 \mathrm{~mm}$ & $\begin{array}{l}\text { double-handed } \\
\text { blade strike }\end{array}$ & depression & $51 \mathrm{~mm}$ & $37 \mathrm{~mm}$ & $\begin{array}{l}\text { four large secondary } \\
\text { radiating fracture } \\
\text { lines }\end{array}$ \\
\hline $5 \mathrm{~mm}$ & $\begin{array}{l}\text { double-handed } \\
\text { blade strike }\end{array}$ & depression & $111 \mathrm{~mm}$ & $80 \mathrm{~mm}$ & $\begin{array}{l}\text { three large and many } \\
\text { small secondary } \\
\text { radiating fracture } \\
\text { lines; tertiary } \\
\text { fracture causing the } \\
\text { large area of } \\
\text { displaced bone }\end{array}$ \\
\hline $7 \mathrm{~mm}$ & pommel blow & linear & $32 \mathrm{~mm}$ & $<1 \mathrm{~mm}$ & none \\
\hline $5 \mathrm{~mm}$ & pommel blow & linear & $40 \mathrm{~mm}$ & $<1 \mathrm{~mm}$ & none \\
\hline
\end{tabular}

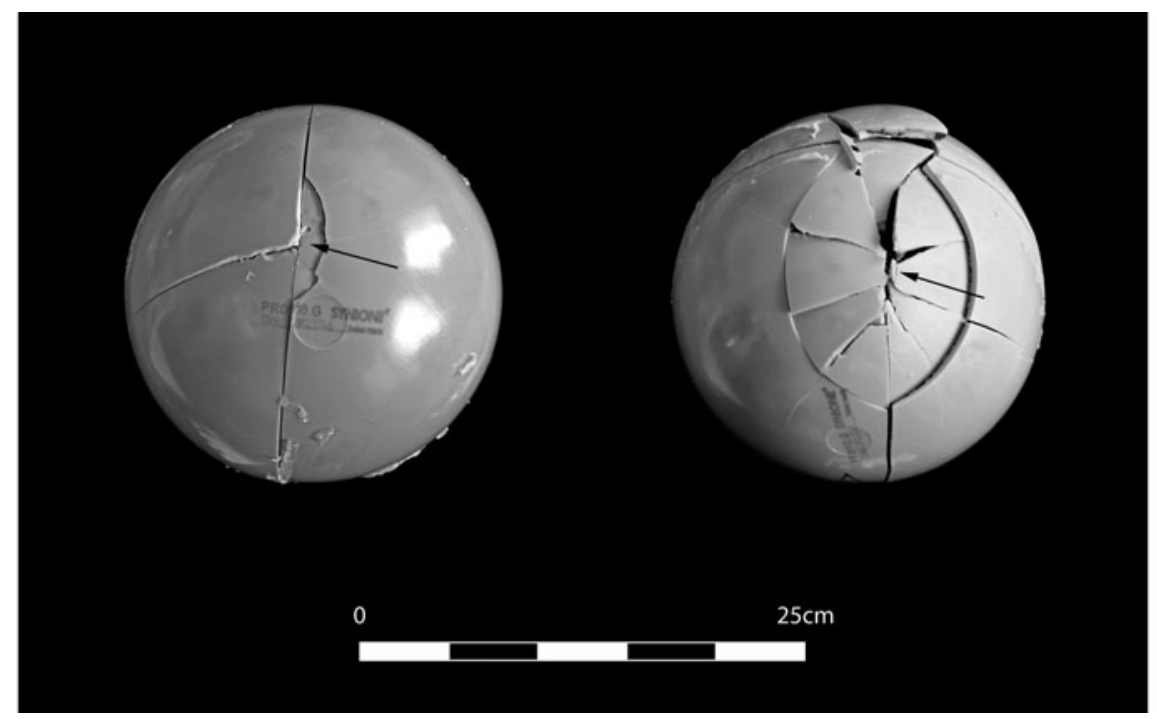

Figure 5. Impact site of the $7 m m$-thick sphere (left), and $5 m m$-thick sphere (right), both with central areas of depressed bone surrounded by radiating fracture lines. Arrows indicate the point of impact (photograph: Meaghan Dyer).

Ultimately, synthetic bone adequately represents the biomechanical properties of the frontal and parietal bones of living human crania (Thali et al. 2002a: 199, 2002b: 181; Carr et al. 2015: 506; Smith et al. 2015: 434). The lack of cranial sutures and buttressing in the test model does, however, influence fracture formation, and the stepped pattern of the bevelled depression fracture edges would tend to have a much smoother appearance in actual human bone.

(C) Antiquity Publications Ltd, 2017 


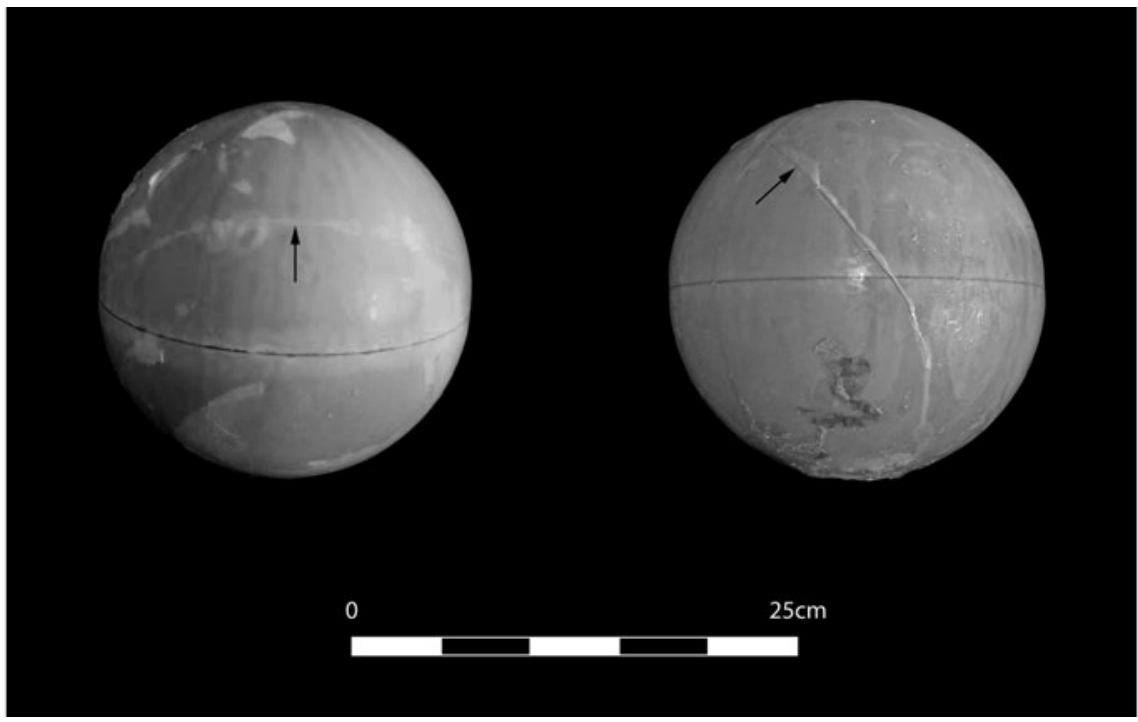

Figure 6. Linear fractures produced by the pommel strikes on the $7 m m$-thick (left) and $5 m m$-thick (right) spheres. Arrows indicate the point of impact (photograph: Meaghan Dyer).

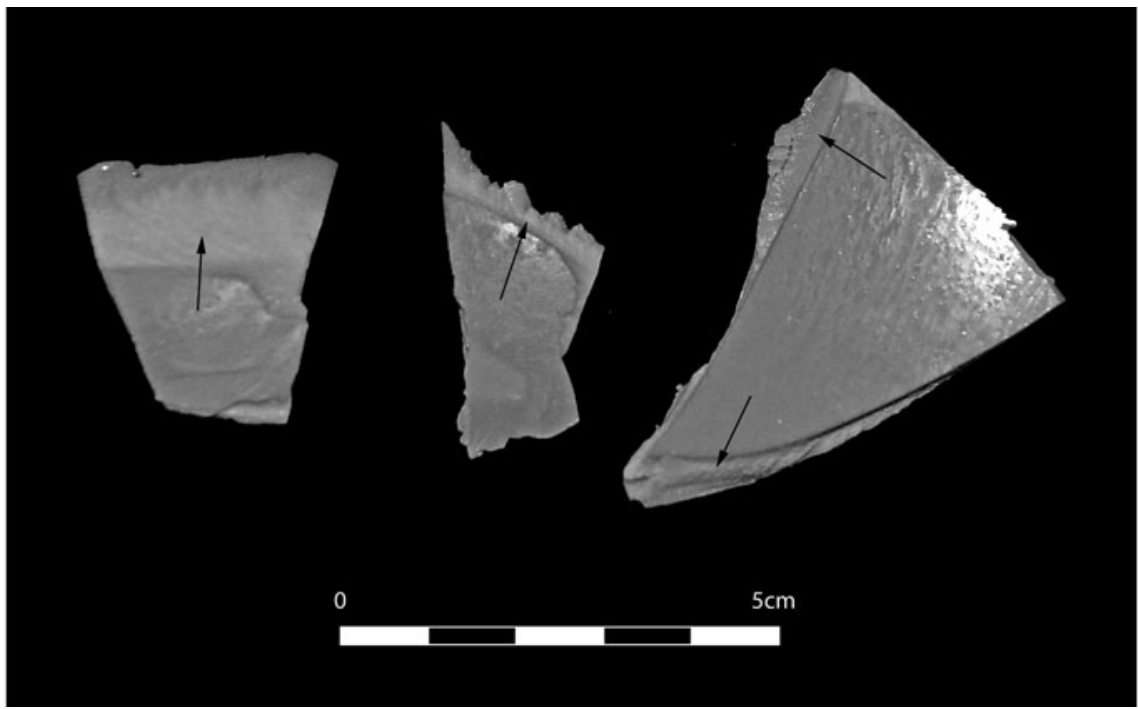

Figure 7. Displaced synthetic bone fragments from the double-handed strikes. Bevelled edges are indicated by arrows (photograph: Meaghan Dyer).

Most importantly, synthetic bone models remove ethical and legal issues, are cost effective, easily obtainable, able to respond biomechanically in a way that is much closer to real human skull material than can be achieved using animal substitutes, and provide a standardised model for testing (Thali et al. 2002b: 178; Carr et al. 2015: 506; Smith et al. 2015: 427). 


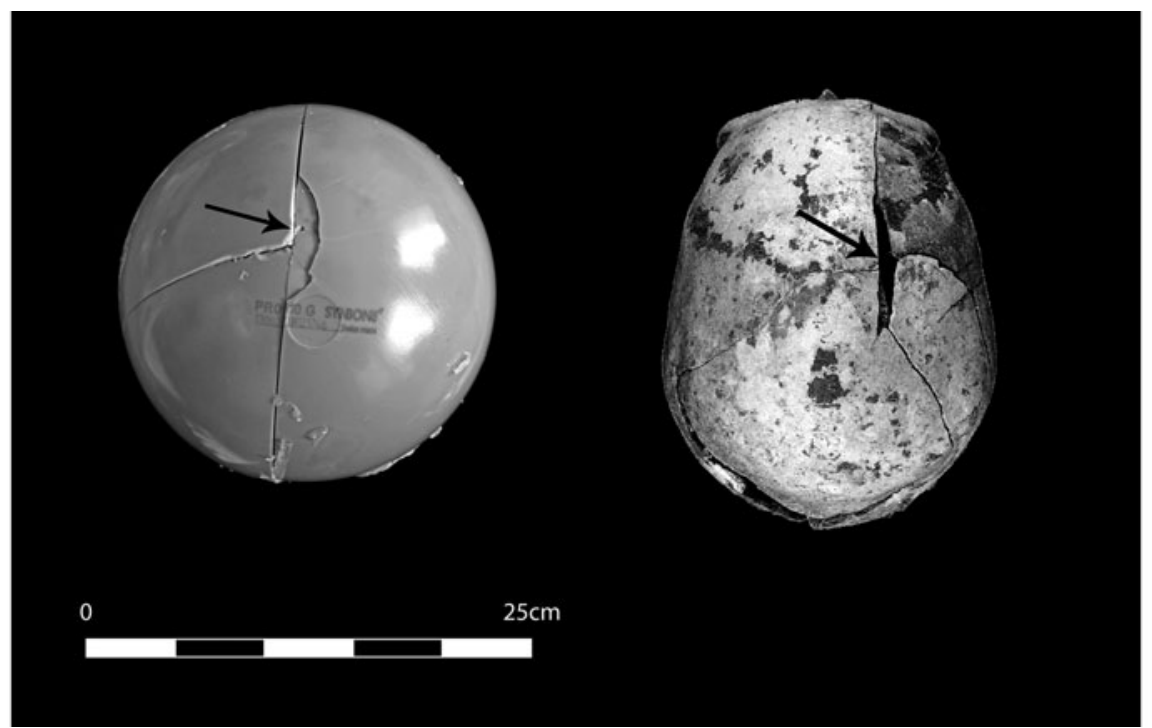

Figure 8. Comparison between the depression fractures on the $7 m m$-thick sphere, and the fractures found on individual 3, a 35-40-year-old male, at the site of Asparn/Schultz (skull not to scale) (Synbone sphere photograph on left: Meaghan Dyer; Asparn/Schletz cranium on right adapted from Teschler-Nicola 2012).

\section{Archaeological comparisons-double-handed strikes}

The depression fractures formed by the double-handed blade strikes to the skin-skull-brain models bear a significant resemblance to examples of violence-related blunt force trauma in the Neolithic osteological record. The fracture morphology, shape of displaced fragments and the bevelled fracture edges produced in both spheres very closely match trauma linked to wooden clubs (Teschler-Nicola et al. 1996; Schulting \& Wysocki 2005: 125; TeschlerNicola 2012: 108).

The fractures present on the $7 \mathrm{~mm}$-thick sphere wall bear remarkable similarity to injuries recorded on individual 3, a 35-40-year-old male from the Neolithic Austrian site of Asparn/Schletz (Teschler-Nicola et al. 1996; Teschler-Nicola 2012: 107). As Figure 8 shows, both skulls have a long, thin depression near the top of the skull, with several radiating fractures. The impact sites on both also have one straight and one slightly curved border. This is a remarkable match between the archaeological record and the experimental results.

The stark similarities between the experimental models and the archaeological specimens provide a link between many of the cases of cranial trauma noted in the archaeological record and the argument that wooden clubs were used as weapons of violence. Asparn/Schletz represents a single-event massacre site (Teschler-Nicola 2012: 108; Meyer et al. 2015: 11217), and the clearly lethal nature of the tested wooden club fits the presumed motivation of intent to kill. It remains to be established whether this type of weapon could also produce some of the healed trauma found in Neolithic population studies. If so, an interpretation would be required that considered why some individuals were able to survive attacks with such a lethal tool. Alternatively, different weapon types might suggest different types of violence. These questions are currently being addressed in an ongoing study.

(C) Antiquity Publications Ltd, 2017 


\section{The anomalous linear fractures}

The strikes made with the pommel end of the club deviated greatly from our expectations that the small, rounded surface combined with a more controlled 'swing' would produce small, non-lethal depression fractures. Instead, a distinct linear fracture formed, radiating out from the point of contact. Therefore, the lower impact energy that causes linear fractures may indeed result from intentional violence or accidental trauma (Ta'ala et al. 2006: 996; Sahoo et al. 2013; Freeman et al. 2014: 64; Wedel \& Galloway 2014: 137). The ambiguity created due to linear fractures forming during accidental and violence-related trauma means that these fractures are commonly excluded in considerations of violence in archaeological trauma studies (Lovell 1997: 154; Ortner 2003: 121; Schulting \& Wysocki 2005: 110).

The formation of these fractures may be due to the properties of the synthetic bone. This issue requires further experimental studies, but the presence of documented cases of linear fracture formation from intentional injury lends credence to the idea that blows of a lower impact energy did produce this kind of injury during violent interaction (Ta'ala et al. 2006: 996; Sahoo et al. 2013; Wedel \& Galloway 2014: 137). The hand placement for the pommel-led strikes greatly limited the swing distance and energy of the attack. The decrease in energy is the most probable reason for linear fracture (Lovell 1997: 150; Ortner 2003: 121).

\section{Wooden clubs as weapons of violence}

Although the Thames Beater is a single artefact from England, it provides a good example of the wooden clubs that could have been crafted during the European Neolithic and beyond, and is broadly representative of this general category of implement. The strong correlation between the experimental injuries inflicted by the Thames Beater and the archaeological cases from Asparn/Schletz lends potential support to the theory that wooden clubs were used as short-range weapons of interpersonal violence in Neolithic Europe. With the recent rise in studies of both population and individual sites, information about violence in the Neolithic period has increased, with extensive variation in the interpretation of its social context including highly ritualised individual combat, informal raiding and war (Keeley 1996; Golitko \& Keeley 2007: 332; Boulestin et al. 2009; Schulting \& Fibiger 2012: 2).

Violent events in the Neolithic probably occurred for a variety of reasons, preventing any attempt at a singular contextual explanation (Chenal et al. 2015: 1329). A better understanding of the weapons used at massacre sites such as Talheim, SchöneckKilianstädten and Asparn/Schletz, and in cases of lower-level endemic violence as documented in larger population studies, could help to improve our understanding of different types of violent behaviour in Neolithic society (Ahlström \& Molnar 2012: 17; Schulting 2012: 223; Teschler-Nicola 2012: 108; Wahl \& Trautmann 2012: 85; Fibiger et al. 2013: 190).

\section{Conclusion}

This study demonstrates a probable connection between what was probably a widespread type of Neolithic weapon and examples of blunt force cranial trauma recorded in the 
archaeological record. In particular, it matches trauma in at least one individual from Asparn/Schletz. These results are the first to link a particular weapon to blunt force injury recorded from the Neolithic. Further research is currently being undertaken to test other potential weapons, and explore whether they can be differentiated according to the cranial fracture patterns that they produce.

The methodology established here can be applied to studies of other suspected Neolithic weapons to establish variations in the kinds of violence involved. This should provide a better contextualisation of Neolithic violence and the mechanisms by which it was enacted, and thus create a better understanding more generally of social interactions and pressures that led to different forms of violence across Western and Central Europe during this time.

\section{Acknowledgements}

The authors kindly thank Maria Teschler-Nicola for her permission to reproduce the images of the Asparn/Schletz individual. Thanks also go to David Lewis, Rebecca Redfern and the Museum of London, Debra Carr and Ian Horsfall of the 'Impact and Armour Group' at Cranfield University, Steven Symes, Rick Schulting, Matt Wells, Aleksa Alacia and Jürgen van Wessel. The authors would also like to thank the two anonymous reviewers for their helpful comments.

\section{References}

Adeloye, A., K.R. Kattan \& F.N. Silverman. 1975. Thickness of the normal skull in the American blacks and whites. American Journal of Physical Anthropology 43: 23-30. https://doi.org/10.1002/ ajpa.1330430105

Ahlström, T. \& P. Molnar. 2012. The placement of the feathers: violence among sub-boreal foragers from Gotland, central Baltic Sea, in R.J. Schulting \& L. Fibiger (ed.) Sticks, stones and broken bones: Neolithic violence in a European perspective: 17-33. Oxford: Oxford University Press. https://doi.org/ 10.1093/acprof:osobl/9780199573066.003.0002

Alcantara, A.L., M.H. Roszler, A.M. Guyot \& P.L. Peterson. 1994. Blunt head trauma: comparison of various weapons with intracranial injury and neurologic outcome. Journal of Trauma 37: 521-24. https://doi.org/10.1097/ 00005373-199410000-00001

Boulestin, B., A. Zeeb-Lanz, C. Jeunesse, F. HaAck, R.-M. Arbogast \& A. Denaire. 2009. Mass cannibalism in the Linear Pottery Culture at Herxheim (Palatinate, Germany). Antiquity 83: 968-82. https://doi.org/10.1017/ S0003598X00099282

Byard, R., G. Cains \& J. Gilbert. 2007. Use of pig models to demonstrate vulnerability of major neck vessels to inflicted trauma from common household items. American Journal of Forensic Medicine and Pathology 28: 31-34. https://doi.org/10.1097/ 01.paf.0000233530.18744.07
Calc, S.E. \& T.L. Rogers. 2007. Taphonomic changes to blunt force trauma: a preliminary study. Journal of Forensic Science 52: 519-27. https://doi.org/ $10.1111 /$ j.1556-4029.2007.00405.x

Carr, D., A. Lindstrom, A. Jareborg, S. Champion, N. Waddell, D. Miller, M. Teagle, I. Horsfall \& J. KIESER. 2015. Development of a skull/brain model for military wound ballistics studies. International Journal of Legal Medicine 129: 505-10. https://doi.org/10.1007/s00414-0141073-2

Chattopadhyay, S. \& C. Tripathi. 2010. Skull fracture and haemorrhage pattern among fatal and nonfatal head injury assault victims - a critical analysis. Journal of Injury and Violence Research 2: 99-103. https://doi.org/10.5249/jivr.v2i2.46

Chenal, F., B. Perrin, H. Barrand-Emam \& B. Boulestin. 2015. A farewell to arms: a deposit of human limbs and bodies at Bergheim, France, c. 4000 BC. Antiquity 89: 1313-30. https://doi.org/10.15184/aqy.2015.180

Christensen, J. 2004. Warfare in the European Neolithic. Acta Archaeologica 75: 129-56. https:// doi.org/10.1111/j.0065-001X.2004.00014.x

Corey, C.Z., M.D. Jones, D.S. James, S. Leadbeatter \& L.D. Nokes. 2001. The potential and limitations of utilising head impact injury models to assess the likelihood of significant head injury in infants after a fall. Forensic Science International 123: 89-106. https://doi.org/ 10.1016/S0379-0738(01)00523-0 


\section{Understanding blunt force trauma and violence in Neolithic Europe}

Dujovny, M., I. Onyekachi \& E. Perez-Arjona. 2009. Baseball bats: a silent weapon. Neurological Research 31: 1005-11. https://doi.org/10.1179/174313209X385716

FACKLER, M.L. \& J.A. Malinowski. 1988. Ordnance gelatin for ballistic studies. Journal of Forensic Medicine and Pathology 9: 218-19. https://doi.org/10.1097/00000433-19880900000008

Fibiger, L. 2014. Misplaced childhood? Interpersonal violence and children in Neolithic Europe, in C. Knüsel \& M. Smith (ed.) The Routledge handbook of the bioarchaeology of human conflict: 127-45. Abingdon: Routledge.

Fibiger, L., T. Ahlström, P. Bennike \& R.J. Schulting. 2013. Patterns of violence-related skull trauma in Neolithic southern Scandinavia. American Journal of Physical Anthropology 150: 190-202. https://doi.org/10.1002/ajpa.22192

Fowler, C. 2010. Patterns and diversity in the Early Neolithic mortuary practices of Britain and Ireland: contextualizing the treatment of the dead. Documenta Praehistorica 37: 1-22. https://doi.org/10.4312/dp.37.1

Freeman, M.D., A. Eriksson \& W. Leith. 2014. Head and neck injury patterns in fatal falls: epidemiologic and biomechanical considerations. Journal of Forensic and Legal Medicine 21: 64-70. https://doi.org/10.1016/j.jflm.2013.08.005

Getz, B. 1961. Skull thickness in the frontal and parietal regions. Acta Morphologica Neerlando-Scandinavica 3: 221-28.

Golitko, M. \& L. Keeley. 2007. Beating ploughshares back into swords: warfare in the Linearbandkeramik. Antiquity 81: 332-42. https://doi.org/10.1017/S0003598X00095211

JaCobsen, C., B.H. BeCH \& N. LyNnerup. 2009. A comparative study of cranial, blunt trauma fractures as seen at medicolegal autopsy and by computed tomography. BMC Medical Imaging 9: article no. 18. https://doi.org/10.1186/1471-2342-9-18

Jussila, J. 2004. Preparing ballistic gelatin-review and proposal for a standard method. Forensic Science International 141: 91-98. https://doi.org/10.1016/j.forsciint.2003.11.036

Kasrai, L., T. Hearn, E. Gur \& C.R. Forrest. 1999. A biomechanical analysis of the orbitozygomatic complex in human cadavers: examination of load sharing and failure patterns following fixation with titanium and bioresorbable plating systems. Journal of Craniofacial Surgery 10: 237-43. https://doi.org/10.1097/00001665-19990500000012
KeELEY, L.H. 1996. War before civilization: the myth of the peaceful savage. Oxford: Oxford University Press.

LAWRENCE, D. 2006. Neolithic mortuary practice in Orkney. Proceedings of the Society of Antiquaries of Scotland 136: 47-60.

Lieberman, D.E. 1996. How and why humans grow thin skulls: experimental evidence for systemic cortical robusticity. American Journal of Physical Anthropology 101: 217-36. https://doi.org/ 10.1002/(SICI)1096-8644(199610)101:2<217:: AID-AJPA7>3.0.CO;2-Z

LORKIEWICZ, W. 2011. Unusual burial from an Early Neolithic site of the Lengyel Culture in central Poland: punishment, violence or mortuary behavior? International Journal of Osteoarchaeology 21: 428-34. https://doi.org/10.1002/oa.1149

LovelL, N.C. 1997. Trauma analysis in paleopathology. American Journal of Physical Anthropology 104: 139-70. https://doi.org/10.1002/(SICI) 10968644(1997)25+<139::AID-AJPA6>3.0.CO;2-\#

LyNnerup, N. 2001. Cranial thickness in relation to age, sex and general body build in a Danish forensic sample. Forensic Science International 117: 45-51. https://doi.org/10.1016/S0379-0738(00)00447-3

McKinley, J.I. 2008. The human remains, in R.J. Mercer \& F. Healy (ed.) Hambledon Hill, Dorset, England. Excavation and survey of a Neolithic monument complex and its surrounding landscape: 477-521. London: English Heritage.

Meyer, C., C. Lohr, D. Gronenborn \& K.W. Alt. 2015. The massacre mass grave of Schöneck-Kilianstädten reveals new insights into collective violence in Early Neolithic Central Europe. Proceedings of the National Academy of Sciences of the USA 112: 11217-22. https://doi.org/10.1073/pnas. 1504365112

Oн, S. 1983. Clinical and experimental morphological study of depressed skull fracture. Acta Neurochirurgica 68: 111-21. https://doi.org/10.1007/BF01406207

OrTner, D.J. 2003. Identification of pathological conditions in human skeletal remains. New York: Academic Press.

Raul, J., C. Deck, R. Willinger \& B. Ludes. 2008. Finite-element models of the human head and their applications in forensic practice. International Journal of Legal Medicine 122: 359-66. https://doi.org/10.1007/s00414-008-0248-0

Sahoo, D., C. Deck, N. Yoganandan \& R. Willinger. 2013. Anisotropic composite human skull model and skull fracture validation against temporo-parietal skull fracture. Journal of the Mechanical Behaviour of Biomedical Materials 28: 340-53. https://doi.org/10.1016/j.jmbbm. 2013.08.010 
Schulting, R.J. 2012. Skeletal evidence for interpersonal violence: beyond mortuary monuments in southern Britain, in R.J. Schulting \& L. Fibiger (ed.) Sticks, stones, and broken bones: Neolithic violence in a European perspective: 223-48. Oxford: Oxford University Press. https://doi.org/10.1093/ acprof:osobl/9780199573066.003.0013

Schulting, R.J. \& L. Fibiger. 2012. Skeletal evidence for interpersonal violence in the Neolithic, in R.J. Schulting \& L. Fibiger (ed.) Sticks, stones, and broken bones: Neolithic violence in a European perspective: 1-16. Oxford: Oxford University Press. https://doi.org/10.1093/acprof:osobl/ 9780199573066.003 .0001

Schulting, R. \& M. Wysocki. 2005. 'In this chambered tumulus were found cleft skulls...': an assessment of the evidence for cranial trauma in the British Neolithic. Proceedings of the Prehistoric Society 71: 107-38. https://doi.org/10.1017/S0079497X00000979

Sharkey, E., M. Cassidy, J. Brady, M. Gilchrist \& N. NicDaEID. 2012. Investigation of force associated with the formation of lacerations and skull fractures. International Journal of Legal Medicine 126: 835-44. https://doi.org/10.1007/s00414-011-0608-z

Smith, M. \& M. Brickley. 2007. Boles Barrow: witness to an ancient violence. British Archaeology 93: 22-27.

Smith, M.J., S. James, T. Pover, N. Ball, V. Barnetson, B. Foster, C. Guy, J. Rickman \& V. Walton. 2015. Fantastic plastic? Experimental evaluation of polyurethane bone substitutes as bone proxies for human bone in trauma simulation. Legal Medicine 17: 427-35. https://doi.org/10.1016/j.legalmed.2015.06.007

Synbone AG. 2013. SYNBONE anatomical models for education: ballistics testing products. Available at: https://www.synbone.ch/wEnglish/catalogue/ categories.php? navanchor $=1010049$ (accessed 30 June 2017).

TA'Ala, S.C., G.E. Berg \& K. Haden. 2006. Blunt force cranial trauma in the Cambodian killing fields. Journal of Forensic Science 51: 996-1001. https://doi.org/10.1111/j.15564029.2006.00219.x
Teschler-Nicola, M. 2012. The Early Neolithic site Asparn/Schletz (Lower Austria): anthropological evidence of interpersonal violence, in R.J. Schulting \& L. Fibiger (ed.) Sticks, stones, and broken bones: Neolithic violence in a European perspective: 101-20. Oxford: Oxford University Press. https://doi.org/ 10.1093/acprof:osobl/9780199573066.003.0006

Teschler-Nicola, M., F. Gerold, F. Kanz, K. Lindenbauer \& M. Spannagl. 1996. Anthropologische Spurensicherung-Die traumatischen und postmortalen Veränderungen an den linearbandkeramischen Skelettresten von Asparn/Schletz, in H. Windl (ed.) Rätsel um Gewalt und Tod vor 7000 Jahren, eine Spurensicherung: 47-61. Wien: Niederösterreichisches Landesregierung.

Thali, M.J., B.P. Kneubuehl \& R. Dirnhofer. 2002a. A 'skin-skull-brain model' for the biomechanical reconstruction of blunt forces to the human head. Forensic Science International 125: 195-200. https://doi.org/10.1016/S03790738(01)00639-9

Thali, M.J., B.P. Kneubuehl, U. Zollinger \& R. Dirnhofer. 2002b. The 'skin-skull-brain model': a new instrument for the study of gunshot effects. Forensic Science International 125: 178-89. https://doi.org/10.1016/S0379-0738(01)00637-5

Wahl, J. \& I. Trautmann. 2012. The Neolithic massacre at Talheim: a pivotal find in conflict archaeology, in R.J. Schulting \& L. Fibiger (ed.) Sticks, stones, and broken bones: Neolithic violence in a European perspective: 77-100. Oxford: Oxford University Press. https://doi.org/10.1093/acprof: osobl/9780199573066.003.0005

Walker, P.L. 1989. Cranial injuries as evidence of violence in prehistoric southern California. American Journal of Physical Anthropology 80: 313-23. https://doi.org/10.1002/ajpa.1330800305

Webber, M. \& H. Ganiaris. 2004. The Chelsea club: a Neolithic wooden artifact from the River Thames in London, in J. Cotton \& D. Field (ed.) Towards a new Stone Age: aspects of the Neolithic in south-east England (Council for British Archaeology Research Report 137): 124-27. York: Council for British Archaeology.

Wedel, V.L. \& H. Galloway. 2014. Broken bones: anthropological analysis of blunt force trauma. Springfield (IL): Charles C. Thomas.

Received: 20 July 2016; Accepted: 24 October 2016; Revised: 10 November 2016

(C) Antiquity Publications Ltd, 2017 